\title{
A Study on Biofilm Formation in Relation to Oral Hygiene Status Related to Tooth Brushing Practice
}

\author{
Dr. Tamanna Akbar ${ }^{1}$, Dr. Hasibul Hasan², Dr. Md. Abdul Awal' ${ }^{3}$, Milon Kumar Ghosh ${ }^{4}$, \\ Dr. Md.JawadulHaque ${ }^{5}$,Dr.Nihar Sultana ${ }^{6}$
}

Received: 05 March $2017 \quad$ Accepted: 19 April 2017

Abstract:

Introduction:The aim of the present study was to assess the biofilm formation in oral cavity and its relationship with oral hygiene status related to practice of tooth brushing among school going children in Rajshahi, Bangladesh. Materials and methods: A descriptive cross-sectional study was carried out among the 386 school going children with age range of 6-16 years old. The study was carried out in the police line school, Rajshahi. Data were collected through a semi-structured questionnaire and analyzedby using SPSS software version 21.0. Result: The most prevalent age group of the study was 6-11 years with frequency 192(49.7\%). The proportion of the boys and girls was1.71: 1. It was found that 243(66.8\%) students learnt about tooth brushing from their family and235(60.9\%) of total studentsbrush their tooth once in a day. Majority367(95.1\%) of them use tooth paste as dentifrices and377(97.7\%) use tooth brush as tooth brushing instrument. Only 2(0.5\%)studentsdo not brush their teeth at all. We also found, that mostof them 274(71\%) used horizontal tooth brushing technique. This study showed the relationship between practice of tooth brushing of the respondents' and the index of biofilm formationthat was statistically insignificant ( $p>0.05)$, but relationship between respondents' oral hygiene status and biofilm formation is statistically significant $(p<0.05)$. Conclusion: It was assessing that state of oral hygiene condition of school going children can be improved by prevention of biofilm formation, and also suggesting to ensure the practice of regular brushing of teeth.

Key Word: Oral hygiene Status, Biofilm, Tooth Brushing.

\section{Introduction:}

Oral health care is one of the abandoned issues in our community. In the other hand oral hygiene maintenance is the cheapest form of preventive health measure. Though cheap, it is surprisingly one of the most ignored practices especially in the underprivileged rural communities. School going children should have sufficient knowledge of understanding the value of maintaining health practices, which in turn results bacterial accumulation in oral cavity and initially causes formation of a biofilm which is known as dental plaque [ ]. The first step in biofilm development is the adsorption of host and bacterial molecules on the tooth surface. Within minutes of tooth eruption or a cleaning, pellicle formation begins, which can be defined as a thin coat of salivary proteins [ ].The pellicle acts like an adhesive by sticking to the tooth surface and encourage a conditioning film of bacteria to attach to the pellicle. This conditioning film directly influences the initial microbial colonization, and continues to adsorb bacteria on the tooth surface. Initially the biofilm is soft enough to come off

1. Lecturer, Department of Paediatric Dentistry, Udayan Dental College, Rajshahi. PhD Fellow, University of Rajshahi.

2. Associated Professor and Head of the Conservative Dentistry \&EndodonticsDepartment, Udayan Dental College, Rajshahi.

3. Lecturer, Department of Public Health, Varendra University, Rajshahi

4. Lecturer, Department of Pharmacy, TMSS, Medical Technology Institute, Bogra.

5. Professor and Head of the Department of Community Medicine, Rajshahi Medical College, Rajshahi. 6. Assistant Professor, Department of Oral Anatomy and Physiology, Mandy Dental College, Dhaka; PhD Research Fellow (Bangladesh University of Professionals).

Correspondence : Dr. Tamanna Akbar, Phone: 01677-069259. email- tamannaakbar@gmail.com 
by using the fingernail. However, it starts to harden within 48 hours, and in about 10 days the biofilm becomes hard and difficult to remove. This tarter happens when biofilm is not removed by regular brushing or flossing. Tooth brushing is the only way to remove biofilm on the tooth surface and decrease negative impact of it [, ]. The most common procedure to removed dental biofilm involves using a tooth paste and tooth brush [ , ].The present concept of tooth brushing involved around the beginning of the nineteenth century. Prior to that time, wooden "chew stick" or forms of tooth picks were used after meals have not changed from earlier times. Usually dental biofilm can be prevented by mechanical and chemical way. For community level if we want to improve oral health, we have to ensure knowledge for prevention within the community people as well as their practices. To create positive health among the people, oro-dental health is to be given as serious thought along with other factors necessary for promotion of health [ ]. It imposes a challenge of developing culturally acceptable and sensitive program that has the potential to provide knowledge and develop a health attitude in the population concerning oral health or by way of integrating scientific knowledge into traditional oral health beliefs[ ]. The aim of the study was to assess the biofilm formation in oral cavity and its relationship with oral hygiene status related to tooth brushing practice among school going children.

\section{Materials and methods}

This descriptive cross sectional study was carried out at police line school, Rajshahi during the period of May 2013 to December 2014. Sample was collected from 386 healthy students within the age range 6-16 years. Data were collected from the respondents by using semi structured interview administered questionnaire and oral examination after taking verbal consent from the concerned authority as well as from the respondents. In this study simplified oral hygiene index [10] was followed to assess the overall oral hygiene status depending on accumulation of food debris, calculus, gingiva alone with mucous membrane and periodontal condition and Dental plaque index was assessed According to Silness and Löe, (1964) [ ] where Score 1, Score 2 and Score 3 was denoted as mild plaque, moderate plaque and severe plaque respectively. Finally data analysis was done by using the SPSS software version 21. The results of the study have been presented in the following section by the tables, graph, charts and description.

\section{Results:}

Table 1: Distribution of respondents according to socio demographic characteristics. $(n=386)$

\begin{tabular}{|l|c|c|}
\hline \multirow{2}{*}{$\begin{array}{c}\text { Socio demographic } \\
\text { characteristics }\end{array}$} & \multicolumn{2}{|c|}{ Frequency } \\
\cline { 2 - 3 } & Variable & $\mathbf{n}(\%)$ \\
\hline \multirow{3}{*}{ Age groups in year } & $<6$ years & $18(4.7)$ \\
\cline { 2 - 3 } & $6-11$ years & $192(49.7)$ \\
\cline { 2 - 3 } Sex & $>11$ years & $176(45.6)$ \\
\hline \multirow{3}{*}{ Educational level } & Male & $244(63.21)$ \\
\cline { 2 - 3 } & Female & $142(36.79)$ \\
\cline { 2 - 3 } & Primary & $237(61.4)$ \\
\cline { 2 - 3 } & Junior & $107(27.7)$ \\
\hline
\end{tabular}

Regarding the frequency distribution of socio demographic characteristics (Table-1) it was revealed that majority $192(49.7 \%)$ of the respondents belongs to the age group of 6 -11 years of which $244(63.21 \%)$. The most abundant study group was with primary education level and contributes to $237(61.4 \%)$ followed by junior education level 107 (27.7\%).

Table 2: Distribution of respondents according to their knowledge and practice of tooth brushing. $(n=386)$

\begin{tabular}{|c|c|c|}
\hline $\begin{array}{l}\text { Knowledge and } \\
\text { practice of tooth } \\
\text { brushing }\end{array}$ & Variable & $n(\%)$ \\
\hline \multirow{2}{*}{$\begin{array}{l}\text { Know about tooth } \\
\text { brush }\end{array}$} & Know & $364(94.30)$ \\
\hline & Don't know & $22(5.6)$ \\
\hline \multirow{3}{*}{$\begin{array}{l}\text { Place of knowing } \\
\text { about tooth brushing }\end{array}$} & School & $104(28.6)$ \\
\hline & Family billboards & $243(66.8)$ \\
\hline & Others & $17(4.7)$ \\
\hline \multirow{3}{*}{$\begin{array}{l}\text { Type of dentif rices } \\
\text { use for tooth } \\
\text { brushing }\end{array}$} & Tooth paste & $367(95.1)$ \\
\hline & Tooth powder & $18(4.7)$ \\
\hline & Others & $1(0.3)$ \\
\hline \multirow{2}{*}{$\begin{array}{l}\text { Instrument use for } \\
\text { tooth brushing }\end{array}$} & Tooth brush & $377(97.7)$ \\
\hline & Finger & $9(2.3)$ \\
\hline \multirow{3}{*}{$\begin{array}{l}\text { Frequency of tooth } \\
\text { brushing }\end{array}$} & Daily once & $235(60.9)$ \\
\hline & Daily two times & $148(38.3)$ \\
\hline & Daily three times & $3(0.8)$ \\
\hline \multirow{6}{*}{$\begin{array}{l}\text { Time of tooth } \\
\text { brushing }\end{array}$} & After any meal & $42(10.9)$ \\
\hline & After dinner & $19(4.9)$ \\
\hline & Before breakfast & $213(55.2)$ \\
\hline & Irregularly & $9(2.3)$ \\
\hline & Not at all & $2(0.5)$ \\
\hline & Multiple response & $101(26.2)$ \\
\hline \multirow{3}{*}{$\begin{array}{l}\text { Technique of tooth } \\
\text { brushing }\end{array}$} & Horizontal scrub & $274(71.0)$ \\
\hline & Vertical scrub & $94(24.4)$ \\
\hline & Others & $18(4.7)$ \\
\hline
\end{tabular}

Almost all 364(94.3\%) of the respondent learnt about tooth brushing and within this respondents majority $243(66.8 \%)$ of them learnt this from their family. It also showed that out of 386 students $367(95.1 \%)$ use tooth paste and $377(97.7 \%)$ use tooth brush for their tooth brushing. About the frequency of the teeth brush $235(60.9 \%)$ of the respondents cleaned their teeth once daily and $213(55.2 \%)$ cleaned their mouth before breakfast with this $274(71 \%)$ students use horizontal method of tooth brushing (Table-2). 
Figure 1: Distribution of respondents according to Dental Plaque index. $(n=386)$

\section{Dental Plaque Index}

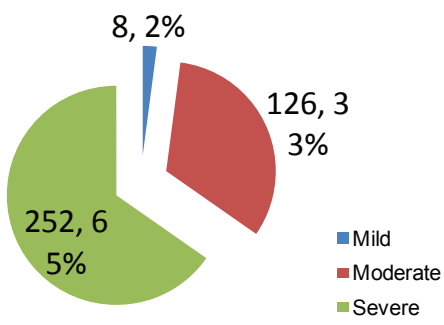

The pie chart (Figure-1) showed Dental Plaque Index of the respondents, where 252(65.3\%) had mild plaque, $126(32.6 \%)$ and $8(2.1 \%)$ had moderate plaque severe plaque respectively.

Figure 2: Distribution of respondents according to Oral hygiene status $(n=386)$

\section{Oral hygiene status}

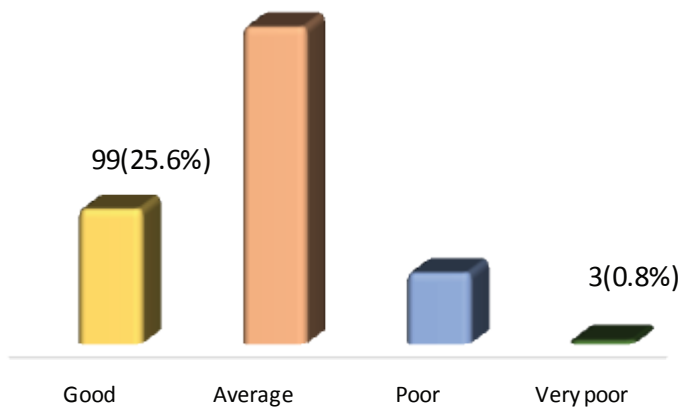

Figure 2 shows that according to simplified oral hygiene index [ ], majority 232(60.1\%) of the respondents had average oral hygiene status followed by $99(25.6 \%)$ with good oral hygiene, 52(13.5\%), 3(0.8\%) poor and very poor oral hygiene status respectively.

Table no 3: Relationship between frequency of tooth brushing of the respondents and dental plaque index.

\begin{tabular}{|c|c|c|c|c|c|}
\hline \multirow{2}{*}{\begin{tabular}{|c|} 
Frequency of \\
tooth \\
brushing
\end{tabular}} & \multicolumn{3}{|c|}{ Dental plaque index } & \multirow[b]{2}{*}{ Total } & \multirow{6}{*}{$p=0.796$} \\
\hline & Mild & Moderate & Severe & & \\
\hline Daily once & $155(66.0 \%)$ & $75(31.9 \%)$ & $5(2.1 \%)$ & $235(60.9 \%)$ & \\
\hline Daily 2 times & $96(64.9 \%)$ & $49(33.1 \%)$ & $3(2.0 \%)$ & 148(38.3\%) & \\
\hline Daily 3 times & 1(33.3\%) & $2(66.7 \%)$ & $0(0 \%)$ & $3(0.8 \%)$ & \\
\hline Total & $252(65.3 \%)$ & $126(32.6 \%)$ & $8(2.1 \%)$ & $386(100.0 \%)$ & \\
\hline
\end{tabular}

$$
\mathrm{X}^{2}=1.668, \mathrm{~d} f=4 ; \mathrm{p}>0.05
$$

Table-3 showed the relationship between frequency of the tooth brushing of the students and the dental plaque index. It was found that respondents brushed once daily had $66.0 \%$ mild dental plaque index whereas who brushed thrice daily had $33.3 \%$ within group. In the other hand, no one with three times brushing daily reported severe dental plaque index but $2.1 \%$ and $2 \%$ people reported with once and twice brushing daily respectively. This relation was found statistically insignificant $(p>0.05)$.

Table no 4: Relationship between oral hygiene status of the respondents and dental plaque index

\begin{tabular}{|c|c|c|c|c|c|}
\hline \multirow{2}{*}{$\begin{array}{l}\text { Oral } \\
\text { hygiene } \\
\text { status }\end{array}$} & \multicolumn{3}{|c|}{ Dental Plaque Index } & \multirow[b]{2}{*}{ Total } & \multirow{7}{*}{$p=0.000$} \\
\hline & Mild & Moderate & Severe & & \\
\hline Good & $96(97.0 \%)$ & $3(3.0 \%)$ & $0(0 \%)$ & $99(25.6 \%)$ & \\
\hline Average & $135(58.2 \%)$ & $97(41.8 \%)$ & $0(.0 \%)$ & $232(60.1 \%)$ & \\
\hline Poor & $21(40.4 \%)$ & $25(48.1 \%)$ & $6(11.5 \%)$ & $52(13.5 \%)$ & \\
\hline Very poor & $0(0 \%)$ & $1(33.3 \%)$ & $2(66.7 \%)$ & $3(0.8 \%)$ & \\
\hline Total & $252(65.3 \%)$ & $126(32.6 \%)$ & $8(2.1 \%)$ & $386(100.0 \%)$ & \\
\hline
\end{tabular}

The association between the oral hygiene status of the respondent and dental plaque index is presented in Table-4. The result showed people with good and average oral hygiene had no severe dental plaque index whereas people with poor and very poor oral hygiene status suffered from severe dental plaque index with value $6(11.5 \%)$ and $2(66.7 \%)$ within group respectively. This result was statistically significant $(p<0.05)$.

\section{Discussion:}

This descriptive cross sectional study was carried out in police line school among 386 school going children of 6-16 years of age group with the objective to assess dental plaque and its relationship with oral hygiene of the school going children in Rajshahi. The study result revealed that out of 386 respondents, majority of them $192(49.7 \%)$ belongs to the age group of 6-11 years. The findings of this study is pertinent with study conducted by U.S. census bureau showed that currently children aged $10-14$ years was more than other age group in Bangladesh (2011 est. $)^{[11]}$. Out of 386 , majority of them $244(63.21 \%$ ) were male and the ratio of male: female was 1.7:1. Currently (2011 est.) under 15 year's male-female ratio of our country is 1.01:1 ${ }^{[11]}$.Regarding source of information of tooth brushing it was revealed that majority of them $243(66.8 \%)$ learned this from their family. Another study done in 3 local government areas of Sokoto state of Nigeria shown that most of 
the mothers $(57 \%)$ did not know that the children have to be assisted in cleaning their teeth till they attained the age of seven ${ }^{[12]}$. In this case the effort of our mother towards children oral health is higher that prevails the higher consciousness of the Bangladeshi people. About using dentifrices, out of 386 student's majority of the students use tooth paste for tooth brushing $367(95.1 \%)$. On the other hand most of the students use tooth brush $377(97.7 \%)$ as tooth brushing instruments. The study also showed that $235(60.9 \%)$ clean their teeth once in a day. In order to prevent oral health problems, the American Dental Association (ADA) recommends tooth brushing at least once a day ${ }^{[13]}$. Regarding the distribution of students by time of tooth brush most of them $213(55.2 \%)$ clean their mouth before breakfast. It was found that $274(71 \%)$ students use horizontal method during tooth brushing (Table-2).In another study of Bangladesh found that $64.8 \%$ respondents brushing should be done after meal and $60 \%$ use vertical scrub method for their tooth brushing ${ }^{[14]}$.Although our findings regarding the time of brushing is significantly differs from the previous study, it may be the good indication that they develop the habit. This study found that regarding oral hygiene status majority of the respondents $232(60.1 \%)$ had average oral hygiene condition (Figure-2). In another study on oral hygiene status of students in selected secondary school in Osogbo, Nigeria stated that $86.8 \%$ of the students had good oral hygiene, $12.1 \%$ have oral hygiene that could be said to be fair, while $1.2 \%$ had poor oral hygiene ${ }^{[13]}$. The result of our study is very negligible with respect to that study which reflects the poor oral health of our society. Regarding dental plaque index, the study result revealed that most of the respondents $65.3 \%$ had mild plaque (Figure-1). To date the most dependable mode of plaque control is mechanical cleaning with tooth brush. Many surveys in different part of the world have found brushing to be the best way to maintain oral health ${ }^{[15]}$. Enwonwu in 2000, found that poor oral hygiene is one of the main cause of Noma ${ }^{[16]}$. The study showed that the frequency of the tooth brushing of the respondent increased, the severity of dental plaque decreased, but this relation was not statistically significant $(p>0.05)$ (Table-3). The study result also showed that oral hygiene status of the respondents had a strongly significant association with dental plaque index $(p<0.05)($ Table-4).

\section{Conclusion:}

Most of the people of our country are not concerned about their oral health due to their lack of knowledge. As a consequence, they suffer from diverse of oral problems. Although some people have the practice of tooth brushing but they apply wrong technique results different kind of oral diseases and not reached the expected level of awareness on oral health. Even though this study was conducted among small sample group, it might provide important information to the citizen to take proper measures to maintain oral health for their children. As it is found significant relationship between oral hygiene status and dental plaque index, so at the end in the light of findings, we may suggest that people should take effective measures to ensure good oral health of their children from the very beginning. Children along with their parents should be given information and importance of tooth brushing to prevent plaque formation. Moreover, oral hygiene instruction should be highlighted through planning, implementation, and evaluation of oral health promotion programs among school going children.

\section{References:}

1. Odell E, Cawson R and S. Porter. "Cawson'sessential of oral pathology and oral medicine", 7thed. Churchikk Livingstone, 1962: 38-39.

2. Anna Frutiger."Adsorption of Host and Bacterial Molecules to the Tooth Surface": Dental Plaque Biofilms(the student-edited microbiology resource). MicrobeWiki, 2010; 20:13

3. Marsh PD. Are Dental diseases examples of ecological catastrophes? Microbiology, 2003; 149(2): 279-94

4. Martens L, Vanobbergen J, Leroy R, Lesaffre E, Declerck D. Variable associated with oral hygiene levels in 7 -year-olds in Belgium. Community Dent Health., 2004;21(1):4-10

5. Strydonck DAC etal. The anti-plaque efficacy in chlorohexidine mouthrinse used in combination with toothbrushing with dentifrice. J clin Periodontol., 2004;31(8):691-5

6. Jain Y. A comparison of the efficacy of powered and manual toothbrushes in controlling plaque and gingivitis. Clin Cosmet Investig Dent., 2013;5:3-9

7. Zhang M, McGrath C, Hagg U. The impact of malocclusion and its treatment on quality of life: a literature review. Int J Paediatr Dent, 2006;16(6):381-87

8. Lee KL, Schwarz, Mak Kyk. Improving Oral health 
through understanding the meaning of health and disease in Chinese culture. Int Dent J., 1993; 43:2-8.

9. Löe $H$. The gingival index, the plaque index and theretention index systems. J Periodontol 1967, 38(suppl.): 610.

10. Greene JC, Vermillion JR. The oral hygiene index: a method for classifying oral hygiene status. JADA., 1960;61(2):172-179

11. Demography of Bangladesh, From Wikipedia, the free encyclopedia

12. Bamigboye $\mathrm{O}$ and Akande TM. Oral Hygiene Status of Students in Selected Secondary School in Osogbo, Nigeria. The Nigerian Medical Practitioner, 2007; 51 (4) 2007: 71-75.

13. PrabhuS. R. Oral Diseases in the Tropics (Oxford Medical Publications).

14. Ahmed MS, Al-Mamun MA, Begum S, Islam MS, Habib MA, Rahman MM. "Knowledge and Practice of tribal People in Rangpur Region Bangladesh", International Journal of Dental Medicine, 2015; 1(3):28-32.

15. Mehrotra V, Gupta R, Sawhny A, Agarwal S, Gupta I, Garg K. Cultural, Religious, Social and Personal Customs "A Boon or Bane" for Oral and General Health. Indian Jouirnal of Dental Education,2013;6(1): 21-32

16. Enwonwu CO, Falkler WA, Idigbe EO. "Oro-facialgangrene (noma/cancrumoris):pathogenic mechanism". Crit Rev Oral Biol Med, 2000; 11(2): 159-71 